Polonia JOURNAL

\title{
MIGRACJE I KULTURA W FILMIE WEGIERSKIM PO UPADKU KOMUNIZMU
}

\section{MIGRATION AND CULTURE IN HUNGARIAN FILM AFTER THE FALL OF COMMUNISM}

\begin{abstract}
ABSTRAKT
W niniejszym tekście autor przedstawia problematykę wpływu ruchów migracyjnych na węgierską kulturę, społeczeństwo, na jego zachowania wobec obcych, przybyszów, przedstawicieli innych narodowości. Węgry po upadku systemu komunistycznego doświadczyły kilkukrotnie fali uchodźców, którzy w poszukiwaniu lepszego lub bezpieczniejszego życia dotarli nad Dunaj. Najpierw byli to przybysze z dawnego Związku Radzieckiego oraz rozpadającej się Jugosławii, później imigranci zarobkowi z Azji, a ostatnio uciekinierzy z terenów objętych wojną w Syrii czy Libii. Za każdym razem zderzenie kultur, spotkanie przedstawicieli różnych narodowości prowadziło do konfrontacji stereotypów z rzeczywistością. Twórcy filmowi na Węgrzech niejednokrotnie ulegali fascynacji tym zjawiskom, w swoich filmach pokazywali wpływ tych wydarzeń na postrzeganie rzeczywistości, rozumienie przez Węgrów otaczającego świata, prezentowali reakcje swoich rodaków: od wrogości, przez obojętność, do współczucia i chęci pomocy. W pracy zostaną ukazane te różnorodne postawy.
\end{abstract}

Słowa kluczowe: migracja, węgierska kultura,stereotyp, twórcy filmowi 


\begin{abstract}
In this text the author presents the problem of the impact of migration movements on Hungarian culture, society, its behavior towards strangers, visitors and representatives of other nationalities. Hungary after the collapse of the communist system experienced several times the wave of refugees who, in search of a better or safer life, reached the Danube. First, they were newcomers from the former Soviet Union and disintegrating Yugoslavia, later economic immigrants from Asia, and recently escapees from war zones in Syria or Libya. Each time a clash of cultures, a meeting of representatives of different nationalities led to the confrontation of stereotypes with reality. Hungarian filmmakers have often been fascinated by these phenomena, in their films they showed the impact of these events on the perception of reality, understanding by the Hungarians the surrounding world, they presented reactions of their countrymen: from hostility, indifference, compassion and to willingness to help. The work will show these various attitudes.
\end{abstract}

Keywords: migration, Hungarian culture, stereotype, filmmaker

Jak większość znanych nam narodów, również Węgrzy w swojej historii doświadczyli spotkania z przedstawicielami innych nacji, ludów, kultur. Już droga plemion węgierskich z okolic Uralu na tereny dzisiejszej ich ojczyzny naznaczona była obcowaniem z mniej lub bardziej wrogo nastawionymi mieszkańcami tamtych terenów. Proces ten trwający setki lat mocno odcisnął się w kulturze Węgrów. Przejmowali zwyczaje, wierzenia, sposoby zdobywania pożywienia walki; do dzisiaj w języku węgierskim odnajdujemy ślady tamtych kontaktów. Do pewnego stopnia sytuacja pozostała niezmienna po osiedleniu się w Kotlinie Naddunajskiej pod koniec IX w. n.e. Zasadnicza różnica polegała na tym, że Węgrzy znaleźli się początkowo głównie w otoczeniu ludów słowiańskich, a nie tureckich. Właściwie cały ten okres, niemal do dnia dzisiejszego, charakteryzował się nieustanną walką o zachowanie odrębności kulturowej, o obronę przed niechcianą asymilacją. Zagrożeniem było Cesarstwo Niemieckie, Imperium Osmańskie, Habsburgowie, Rosja 
później ZSRR. Dla odmiany po upadku systemu komunistycznego Węgry doświadczyły kilkukrotnie fali uchodźców, którzy w poszukiwaniu lepszego lub bezpieczniejszego życia dotarli nad Dunaj. Najpierw byli to przybysze z dawnego Związku Radzieckiego oraz rozpadającej się Jugosławii, później imigranci zarobkowi z Azji, a ostatnio uciekinierzy z terenów objętych wojną w Syrii czy Libii. Za każdym razem zderzenie kultur, spotkanie przedstawicieli różnych narodowości prowadziło do konfrontacji stereotypów z rzeczywistością. W niniejszym tekście przedstawię problematykę wpływu ruchów migracyjnych na węgierską kulturę, społeczeństwo, na jego zachowania wobec obcych, przybyszów, przedstawicieli innych narodowości. Czasem był to proces o charakterze masowym, innym z kolei razem problematyka ma wymiar jednostkowy. Twórcy filmowi na Węgrzech niejednokrotnie ulegali fascynacji tym zjawiskom, w swoich filmach pokazywali wpływ tych wydarzeń na postrzeganie rzeczywistości, rozumienie przez Węgrów otaczającego świata, prezentowali reakcje swoich rodaków: od wrogości, przez obojętność, do współczucia i chęci pomocy. W pracy zostaną ukazane te różnorodne postawy, które możemy odnaleźć w filmie węgierskim ostatnich lat, czyli od upadku komunizmu.

Wczesny okres, o którym wspomniałem, czyli tzw. zajęcie ojczyzny (węg. honfoglalás) w kulturze węgierskiej ma swoje należne miejsce, przyjęto umowną datę dla zakończenia procesu migracyjnego i równocześnie dla początku budowania państwa węgierskiego. Wedle badań historycznych około 896 roku na terenach Kotliny Naddunajskiej pierwsi przedstawiciele plemion węgierskich rozpoczęli długi proces osiedlania się w sprzyjających dla siebie warunkach, kończąc tym samym wieloletnią wędrówkę z obszaru Azji. Spory dotyczące pochodzenia Węgrów trwają do dzisiaj, jednak teoria o ugrofińskich korzeniach wydaje się być najlepiej udokumentowana dzięki badaniom językoznawczym. Wielokrotnie w przeszłości obchodzono kolejne rocznice tamtej daty, wielkim wydarzeniem było 1000-lecie przybycia, kiedy to zorganizowano wysta- 
wę światową w Budapeszcie. Sto lat później, w 1996 roku po raz kolejny przypomniano o tych ważnych dla Węgrów wydarzeniach. Z jednej strony podkreślano własną odrębność kulturową, bogate dziedzictwo przed wkroczeniem do Europy Środkowej, z drugiej natomiast akcentowano ponadtysiącletnią obecność w kręgu cywilizacji zachodnioeuropejskiej, bowiem trzeba zauważyć, że państwo węgierskie bardzo szybko stało się częścią świata chrześcijańskiego. Symboliczny chrzest nastąpił kilka lat po równie symbolicznym akcie na ziemiach polskich, ale za to pierwsza koronacja władcy węgierskiego odbyła się już w 1001, pierwszego dnia nowego milenium ${ }^{1}$.

Liczne oficjalne uroczystości państwowe o charakterze kulturalnym, edukacyjnym, naukowym traktowały owe historyczne wydarzenia $\mathrm{z}$ wielką powagą, bez dystansu do czasami nawet nieudokumentowanych przekazów. Dodatkowym kontekstem była także integracja państwa $\mathrm{z}$ różnego rodzaju strukturami europejskimi, dlatego niemal na każdym kroku podkreślano europejskość Węgrów i powrót do Europy po latach trwającego komunizmu, podobnie zresztą ten proces wyglądał w Polsce.

W tradycji filmowej rok 896 został utrwalony chociażby za sprawą klasycznego ujęcia tego zagadnienia w realizacji Gábora Koltayego Zajęcie ojczyzny (Honfoglalás, 1996) z udziałem włoskiego gwiazdora Franco Nero. O ile dzieło Koltayego była laurką w hołdzie złożonym protoplastom narodu, a także zaspokajało wielkie oczekiwania społeczne nienasycone jeszcze natłokiem okołorocznicowych wydarzeń, o tyle zupełnie inaczej przedstawia się sytuacja $\mathrm{z}$ drugim filmem, Węgierski wędrowiec (Magyar vándor, 2004) Gábora Herendiego, który jest parodią, satyrą na realizację typu kostiumowego, osadzoną silnie w konwencji postmodernistycznej [Varga 2007, s.24].

Film Herendiego powstał kilka lat po hucznie obchodzonej okrągłej rocznicy 1100-lecia zajęcia przez Węgrów swojej dzisiejszej ojczy-

${ }^{1}$ Według innych źródeł stało się w sierpniu 1000 roku. 
zny. Kwestią czasu było więc spojrzenie na tą tematykę z zupełnie innej perspektywy, z przymrużeniem oka, okazało się, że znalezienie inspiracji w obszarach, które pozornie nie stwarzały takiej szansy, było niezwykle twórcze. Faktem stało się również to, że publiczność węgierska zmęczona jednostronną, patriotyczno-martyrologiczną retoryką $\mathrm{z}$ wielkim entuzjazmem przyjęła humorystyczną interpretację własnej etnogenezy. Film zdeklasował inne produkcje i bezapelacyjnie zajął pierwsze miejsce pod względem liczby widzów w roku premiery.

Receptą na spektakularny sukces było, oprócz zaangażowania popularnych aktorów węgierskich, także stworzenie scenariusza, który bazując na utrwalonych stereotypach, podejmował jednak próbę ich zdekonstruowania. Już w pierwszych ujęciach filmu Herendiego odbrązowiony zostaje bohaterski wizerunek założycieli narodu. Przywódcy siedmiu legendarnych plemion węgierskich nie wprowadzają dumnie reszty wędrowników na tereny naddunajskie, jak było to wielokrotnie przedstawiane również $\mathrm{w}$ tradycji malarskiej, ale wręcz tracą $\mathrm{z}$ pola widzenia towarzyszy zamroczeni zbyt dużą ilością wypitego alkoholu. Dalsza akcja filmu będzie dotyczyła usilnych prób odnalezienia zagubionych Węgrów, co stworzy okazję do snucia alternatywnych koncepcji tworzenia się węgierskiej historii. Film Herendiego pełnił funkcję wentyla spuszczającego powietrze z napompowanego wcześniej balonu narodowej dumy. Postacie z filmu Herendiego odziane w stroje z epoki zachowują się jednak jak współcześni bohaterowie, świadczą o tym dialogi, gdzieniegdzie tylko stylizowane na język wczesnego średniowiecza oraz postmodernistyczna gra $\mathrm{z}$ konwencjami, nieustanne mieszanie gatunków.

Trzeba jednak odnotować, że Węgierski wędrowiec nie przecierał szlaków parodii i satyrze $\mathrm{z}$ humorem atakującej podwaliny węgierskiej państwowości, wyśmiewaniu narodowych cech i patetycznych haseł o nacjonalistycznym zabarwieniu. W roku 1999 powstał bowiem zapomniany już właściwie film Andrása Szőke o wielce wymownym tytule 
Helyfoglalás, avagy a mogyorók bejövetelé2, w odróżnieniu od Węgierskiego wędrowca był niskobudżetową realizacją, która nie zdobyła wielotysięcznej publiczności i cieszyła się popularnością wyłącznie w wąskich kręgach na Węgrzech.

Jednak zasadniczym tematem moich rozważań są kwestie ruchów migracyjnych w XX w. i ich wpływu na kulturę oraz społeczeństwo na Węgrzech, dlatego w dalszej części mojego tekstu przedstawię tę problematykę obecną w filmach, które zagadnienia te traktowały jako aktualne, a nie historyczne.

W tym kontekście na uwagę zasługuje film Ibolyi Fekete Bolse vita (1996) pokazany w naszym kraju podczas Lubuskiego Lata Filmowego zdobywca nagrody Złotego Grona. Bolse vita doczekał się również emisji w telewizji publicznej, dzięki czemu był znany szerszej, niż tylko festiwalowa, publiczności.

Fekete zwraca się ku wydarzeniom, które miały miejsce w Europie Środkowej po rozpadzie bloku państw socjalistycznych i zmianie systemu. W swoim debiucie ulega silnej fascynacji efektem wywołanym przez zderzenie wielu kultur, spotkanie się reprezentantów wielu narodowości. Punktem wyjścia dla jej chwilami paradokumentalnej opowieści jest rok 1989, w którym otwarta została granica węgiersko-austriacka, spowodowało to gwałtowny napływ przybyszów z wielu państw, do niedawna socjalistycznych, którzy traktowali Węgry jak państwo tranzytowe w swojej wędrówce na Zachód. Do stolicy kraju ściągali też przedstawiciele tzw. świata zachodniego w poszukiwaniu atrakcji, przeżyć, bowiem słyszeli, że „coś się tam dzieje”. Jak na węgierski film, języka tego narodu jest bardzo niewiele, pada może raptem kilka zdań, reszta

${ }^{2}$ Cały tytuł, jak i poszczególne jego składniki, są grą słów: Helyfoglalás oznacza zajęcia miejsca, ale miejsca konkretnego, co stoi w opozycji do zajęcia ojczyzny Honfoglolás, mogyorók to orzechy, ale wymawia się podobnie do Magyarok czyli Węgrzy. W dosłownym więc tłumaczeniu tytuł brzmi Zajęcie miejsca, czyli przybycie orzechów. 
dialogów to mieszanka rosyjskiego i angielskiego, za pomocą którego próbują się porozumieć bohaterowie filmu: uliczni muzycy z Rosji, ich rodak, z wykształcenia inżynier sprzedający noże na bazarze, Węgierka pomagająca nie zawsze bezinteresownie przybyłym, Walijka ucząca angielskiego i jej przyjaciółka Susan z małego miasteczka w Teksasie. Właściwie dla wszystkich cudzoziemców (ta grupka reprezentuje również w jakimś stopniu masy przepływających imigrantów, którzy chcą stać się emigrantami) Budapeszt jest miejscem przypadkowym, nie planowali na swojej drodze tej lokalizacji. Jura i Vadim zamierzali przedostać się do Jugosławii, a stamtąd może jeszcze dalej do swojej ziemi obiecanej. Inżynier marzy o osiedleniu się we Włoszech, rozpoczęciu nowego, normalnego życia. Maggie szuka wrażeń, chciała się wyrwać z jej zdaniem nudnego, anonimowego życia na Wyspach i z Berlina trafiła na Węgry, prawdopodobnie za namową kogoś, kto jechał w tym kierunku. Podobnie zresztą jak Susan jeżdżąca z miejsca na miejsce, jednego dnia w Wiedniu, drugiego w drodze do Chin. Dlatego też zupełnie nie znają oni specyfiki kraju, w którym przybywają. Dla imigrantów ze Wschodu pobyt to przymus, dla tych drugich chwilowa atrakcja, nie zamierzają więc bliżej poznać miejscowych ludzi, kulturę czy język.

Fabuła filmu spięta jest klamrą autentycznych zdjęć, które nota bene bardzo często wplatane są $\mathrm{w}$ przedstawiane wydarzenia, stając się integralnym elementem dzieła. Rozpoczynają ją wydarzenia niezwykłe, radosne jakimi było otwarcie granic i dużo łatwiejszy niż dotąd przepływ ludzi, bezkrwawe rewolucje w Czechosłowacji i na Węgrzech, bardziej gwałtowne reakcje w Rumunii. Charakter dokumentalny podkreśla również szczególny sposób wypowiedzi bohaterów filmu, czasami zwracają się oni bezpośrednio do kamery przekazując swoje opinie, motywacje nimi kierujące. Fekete portretuje różne typy ludzkie, bezinteresownych artystów, zdeterminowanych poszukiwaczy lepszego życia, otwartych na przybyszów Węgrów, ciekawych świata i znudzonych swoim dotychczasowym życiem mieszkańców Zachodu, ale także obecnych 
podczas zawieruch dziejowych przestępców, bandytów, handlarzy bronią. Reżyserkę najwyraźniej interesuje mętlik jaki mają w umysłach ci ludzie w wyniku błyskawicznie zachodzących przemian, którego biegu nikt nie był w stanie ogarnąć. Ona sama z perspektywy kilku lat stara się zrozumieć to, co stało się również w jej świecie.

Ironiczny tytuł filmu jest zarazem nazwą knajpy, speluny wręcz, do której ściągają przedstawiciele różnych narodowości, krócej lub dłużej przebywający w Budapeszcie. Tam też Jura i Vadim próbują zarobić na życie, kiedy okazało się, że ich podróż na Zachód przynajmniej na razie się nie powiedzie, zwłaszcza, że Vadim jakimś cudem dotarł na Węgry bez ważnych dokumentów. Każdy z bohaterów posiada własne wyobrażenie o otaczającym go świecie, dla Jury Węgry to socjalistyczny Zachód, dla Vadima nowe spostrzeżenia diametralnie różnią się od znanej mu wcześniej rzeczywistości, bo wokół jest normalnie. Erzsi, która przyjmuje imigrantów, przede wszystkim Rosjan, pod swój dach jest po prostu żal, że z tak dumnego narodu stali się żebrakami. Ludzie z Zachodu z jednej strony fascynują się kontaktami z innymi narodami, możliwością nawiązywania bezpośrednich relacji, a z drugiej strony nie są jednak zbyt otwarci na inne kultury. Maggie czy Susan, które przecież mieszkają na Węgrzech, nie wyrażają chęci nauczenia się języka, aby lepiej zrozumieć mieszkańców tego kraju, czekają raczej aż ktoś zagadnie je w ich języku, nawet gdyby to miała być łamana angielszczyzna. Dodaje to z pewnością jakiegoś kolorytu, kiedy na przykład Maggie z Jurą "rozmawiają" o swoich doświadczeniach życiowych, każde mówi we własnym języku, doskonale wiedzą, że druga strona niewiele rozumie, ale odnosi się wrażenie, że bardziej chodzi im o uzewnętrznienie własnym problemów, niewyjawianych nikomu kompleksów.

Fekete pokazuje również jak szybko po krótkotrwałej euforii przychodzi rozczarowanie nową-starą sytuacją. Marzenia w konfrontacji z rzeczywistością pryskają jak bańka mydlana. Tym, którzy już znaleźli się na Węgrzech wydawało się początkowo, że „złapali Pana Boga za 
nogi”, zwłaszcza, że Budapeszt miał być tylko etapem przejściowym (im dalej na zachód, tym może być tylko lepiej), a w konsekwencji nie mogą się z niego wyrwać. Inżynier, którego planem było zarobienie 200 dolarów i szybka ucieczka dalej od Rosji, nie może przekroczyć granicy i czuje się jak w więzieniu, rodzi to frustracje, niechęć podejmowania racjonalnych decyzji. Podobnie Vadim znajduje się w pułapce, ani nie może jechać dalej z powodu braku pieniędzy, ani nie może wrócić bez narażenia się na kłopoty ze względu na brak odpowiednich dokumentów (nie może też starać się o zezwolenie o pracę, chociaż akurat do tego nie ma i tak wielkiego zapału). Jego sytuację dodatkowo komplikuje decyzja Jury, który postanawia wyjechać z Maggie do Walii, by tam założyć rodzinę. Jura przeszedł chyba największą wewnętrzną metamorfozę, z mało odpowiedzialnego, niezbyt zaradnego artysty, któremu wystarczyło do szczęścia parę chwil z gitarą, najlepiej w towarzystwie wódki, stał się świadomym swoich obowiązków człowiekiem. To on namawia Maggie, aby urodziła ich dziecko, aby za niego wyszła, można mu wierzyć, że robi to wyłącznie z miłości, a nie po to, by zabezpieczyć swoją przyszłość, bowiem jest człowiekiem, który nie kalkuluje, nie zastanawia się, co byłoby lepsze, lecz działa spontanicznie.

Frustracje imigrantów pogłębiają zjawiska społeczne, które prędzej czy później muszą się pojawić tam, gdzie obecne są elementy anarchii, gdzie władza nie posiada całkowitej kontroli, a mianowicie działalność grup przestępczych, mafii, handel bronią. O ile wielonarodowy bazar drobnych, indywidualnych handlarzy można jeszcze uznać za lokalny folklor, o tyle pojawienie się uzbrojonych band walczących o własne terytoria jest już poważnym zagrożeniem. Bynajmniej nie są to lokalni przestępcy, ale podążający za rodakami bezwzględni bandyci ze Wschodu. Terroryzują oni na każdym kroku zagubionych w nowej rzeczywistości imigrantów, brutalną siłą zmuszają do posłuszeństwa, odbierają każdy zarobiony z wielkim trudem grosz. Z nimi oczywiście zetkną się bohaterowie filmu i dla inżyniera okaże się to spotkanie tragiczne 
w skutkach, doprowadzające do bezsensownej śmierci. Pojawia się też zupełnie nowe zjawisko towarzyszące rozpadowi Związku Radzieckiego, trudne do przewidzenia nawet dla futurologów, a mianowicie handel materiałami radioaktywnymi, które przemytnicy przewożą przez granice schowane, gdzieś pod płaszczem, jak pieniądze czy jedzenie.

Podjęta jest również kwestia wolności i jej postrzegania przez uczestników wydarzeń, na przykład dla Susan wolność to sposób myślenia. Człowiekowi z wolnego kraju trudno jest zrozumieć, że były i są takie rejony świata, gdzie ludzie właściwie bali się nawet pomyśleć o czymś niepoprawnym politycznie. Dla Rosjan wolność to wolność decyzji, swoboda wyboru, możliwość robienia tego, na co w danej chwili mają ochotę, bez tłumaczenia komukolwiek swoich motywacji. Dlatego też Maggie irytuje sposób, w jaki Jura, według niej bezcelowo, traci czas, ale on po prostu cieszy się swoją wolnością.

W kontekście komunikacji międzykulturowej pojawia się pytanie, co mają sobie wzajemnie do zaoferowania bohaterowie filmu. Płaszczyzną porozumienia jest element ekonomiczny, jako że reprezentanci większości ukazanych narodowości usilnie starają się poprawić swój życiowy standard. Dlatego też miejscem, w którym najczęściej dochodzi do kontaktów, jest bazar. Jego funkcjonowanie jawi się jako swojego rodzaju rytuał odprawiany przez mieszkańców dawnego bloku komunistycznego. Przemycają oni towary przez granice, szukają miejsca do handlu i próbują pozyskać klientów. Innym rytualnym miejscem są bary i klubu o wątpliwej reputacji. Tam wymieniają między sobą sprawdzone adresy, pod którymi można się zatrzymać w trakcie nieustannej wędrówki, tam też muzycy próbują zarobić na życie, kiedy okazuje się, że ich podróż na Zachód, przynajmniej na razie, nie może być kontynuowana. W trakcie dyskusji, w których biorą udział przedstawiciele wielu narodów, konfrontowane są utwierdzane przez dziesięciolecia stereotypy, historyczna wiedza lub jej brak. Okazuje się wówczas, że rosyjski inżynier nigdy nie słyszał o rewolucji w 1956 roku, a tym bardziej o tym, że to właśnie jego 
rodacy ją stłumili. Każdy z bohaterów posiada własne wyobrażenie o otaczającym go świecie - dla jednego Rosjanina Węgry to socjalistyczny Zachód, a drugiemu nic wokół nie przypomina rzeczywistości, którą znał wcześniej. Jak wspomniałem wcześniej, wszyscy oni chociaż mieszkają na Węgrzech, nie zamierzają uczyć się języka, aby lepiej zrozumieć mieszkańców tego kraju, ich kulturę i stać się częścią otaczającego społeczeństwa. Najczęściej z własnego wyboru sytuują się na jego marginesie. $\mathrm{W}$ bardzo niewielkim stopniu dotyczy ich kwestia inkulturacji, podobnie zresztą jak bohaterów innych filmów o tej tematyce.

Czerwony Koliber (Vörös Colibri, 1995) Zsuzsy Böszörményi, który powstał w tym samym okresie, co Bolse vita wykazuje się w stosunku do niego licznymi podobieństwami. Również jest w nim zawarta obserwacja zmian jakie od początku lat dziewięćdziesiątych zaszły w naszej części Europy w wyniku rozpadu starego systemu. Również jest to analiza zachowań, postaw ludzi, których te zmiany dotyczą. Ponownie pojawia się Budapeszt, przybysze ze Wschodu, mafia i konfrontacja marzeń z rzeczywistością. Anna po rozstaniu z mężem wychowuje kilkuletnią córkę i przeważnie wieczorami (bo lepiej płacą) jeździ taksówką, życie jej jest raczej monotonne, ogranicza się głównie do pracy i obowiązków bycia matką. Pewnego dnia przypadkowo poznaje młodego Ukraińca, tancerza usilnie próbującego zrobić artystyczną karierę na Węgrzech. Kobieta nie wie nawet, w którym momencie zakochuje się w przybyszu nieodwzajemniającym jednak jej uczucia, poza kilkoma wspólnie spędzonymi nocami. Andrei, mimo że znalazł się w obcym kraju, nie może narzekać na brak kontaktów ze swoimi rodakami, którzy sprawiają wrażenie, że doskonale dają sobie radę w nowych warunkach i szybko zadomowili się nad Dunajem. Podobnie jak u Fekete nad ich losem czuwa lokalny mafioso, tym razem były oficer Armii Radzieckiej z nostalgią wspominający swój pobyt na Węgrzech jeszcze w czasach socjalizmu. Reżyserka sprawnie wyławia pełne paradoksy historii, jakie towarzyszą szybko toczącym się wydarzeniom. Ukrainiec zatrzymany przez po- 
licję za brak zezwolenia na pobyt stały zostaje osadzony w obozie dla uchodźców, w którym przed rewolucją 56-go roku przetrzymywany był ojciec Anny. Andrei przybywając na Węgry niejako powraca na miejsce, gdzie jego ojciec, żołnierz Armii Radzieckiej, stacjonował okupując ten kraj. On sam będzie teraz szukał tu wolności, spełnienia marzeń, lepszego życia, nie bez powodu ma w plecaku miniaturę Statuy Wolności, która ma mu przypominać o celu w życiu.

Charakterystyczne jest początkowe podejście kobiety do Andreia, najpierw lekceważące (Rosjanie, Ukraińcy dla niej są nie do odróżnienia), towarzyszy temu zaciekawienie (pozwala mu przenocować), ale połączone z nieufnością (zamyka drzwi swojego pokoju na klucz). Nie ma u Węgrów jakiś oznak niechęci, są otwarci, gotowi pomóc ludziom znajdującym się w gorszym położeniu, może dlatego, że wcześniej sami byli mocno doświadczeni przez historię. Zarówno w Bolse vita, jak i w Czerwonym Kolibrze przybysze, chcąc nie chcąc, mają kontakt z lokalnym światem przestępczym, niejednokrotnie stając się jego elementem. Sądzę, że nie jest to przypadek, lecz dowodzi pewnej prawidłowości, iż ludzie z niższych warstw społecznych częściej decydowali się na emigrację, podejmowali ryzyko wyprawy do obcego kraju i łatwiej potrafili się przystosować niż na przykład inteligencja, której przedstawicieli raczej tu nie zobaczymy (tylko w filmie Fekete jest nauczyciel akademicki). Czynnikiem determinującym była kwestia pieniędzy, standardów, dążenia do wygodniejszego życia, bowiem prościej jest wyjechać w nieznane, jeśli żyje się nędznie i bez perspektyw na poprawę.

Również w dialogach Czerwonego Kolibra jest dużo języka rosyjskiego, którego częsta obecność wokół Anny zaczyna sprawiać, że ona sama czuje się jakby była w obcym kraju. Być może wyłącznie za ciekawostkę należy uznać fakt, (ale równie dobrze może to być jakiś znak czasu), że zarówno w jednym, jak i w drugim przypadku tytuł filmu jest równocześnie nazwą lokalu, w którym spotykają się przybyli do Budapesztu 
cudzoziemcy (w Bolse vita to knajpa w piwnicy, w Czerwonym Kolibrze to kiczowaty klub nocny, gdzie przeważnie bawią się przestępcy).

I jeszcze jedno odniesienie do filmu Bolse vita. O tyle istotne, że po prawie dwóch dekadach do pewnego stopnia podobne zderzenie kultur można dostrzec w filmach Pikowanie (Zuhanórepülés, 2007) Erika Nováka i Mix (2004) Stevena Lovy’ego, gdzie Budapeszt jest ponownie tą granicą między Wschodem, a Zachodem. Tu też pojawia się element negatywny przemian ustrojowych, mianowicie zorganizowana przestępczość. Nowy system wprawdzie okrzepł, ale skutki uboczne zamiast zostać zniwelowane coraz bardziej się utrwalają. Mafia z dawnego ZSRR, podobnie jak w Czerwonym Kolibrze doskonale sobie radzi w kapitalistycznej rzeczywistości. W filmie Erika Nováka te wszystkie problemy są doskonale widoczne; Budapeszt jest tyglem wielu narodowości, ale narodowości, które reprezentują świat przestępczy. Pozornie jest barwny, znów mieszają się języki, rasy, jednak w rzeczywistości to całkowicie zdegenerowane środowisko, nie ma w nim egzotyki z Bolse vity, jest tylko brutalność, przemoc i najgorsze instynkty. Główny bohater, którego $\mathrm{w}$ tym świecie więzienie nie jest $\mathrm{w}$ stanie zresocjalizować, stopniowo pogrąża się, mimo że jest przekonany o posiadaniu kontroli nad własnym losem. Usilnie poszukuje własnego miejsca, może i chciałby się wyrwać z tego śmiertelnego kręgu, ale jest za słaby, by oprzeć się pokusom brudnych pieniędzy.

Stolica kraju jako granica Wschodu i Zachodu funkcjonuje tu umownie, bowiem te wpływy już tu są i się mieszają. Sam wizerunek miasta jest niezwykle zdeformowany, składa się z kiczowatych nocnych lokali, przepastnych willi mafiosów, podziemnych parkingów służących za miejsca spotkań gangów, itp. Główny bohater zresztą po wyjściu $\mathrm{z}$ więzienia swoje pierwsze kroki kieruje nie na ulice miasta, by cieszyć się wolnością, ale zmierza wprost do nocnego klubu, by wpaść w narkotykowy i alkoholowy trans. Miasto jako takie nie istnieje, ulice to tylko łączniki pomiędzy podejrzanymi lokalami. Czy te problemy, w efekcie 
tworzą nową, aktualną tożsamość miasta? Być może jest to pewnego rodzaju identyfikacja Budapesztu w nowej rzeczywistości, zwłaszcza, że podobny obraz pojawia się w filmie Mix, chociaż w nim patrzymy na świat oczami przedstawiciela innej kultury, mianowicie młodego Amerykanina z węgierskimi korzeniami. W filmie od pewnego momentu akcja toczy się wyłącznie w nocy, jeśli już pojawi się stolica w naturalnym oświetleniu, to tylko jako przerywnik. Tu też jest element przestępczy, narkotyki, które każdy może bez wysiłku kupić. Filmy łączy ponadto postać grana przez Dorkę Gryllus, uosobienie kobiety uwikłanej w relacje z przestępcami, podporządkowanej kryminalnym mechanizmom ${ }^{3}$. Jej życie w którymś momencie potoczyło się niewłaściwym torem, choć ona sama niczym się nie różni od innych kobiet w jej wieku. Mimo starań nie potrafi odnaleźć drogi powrotnej do normalności.

Ukazane w obu obrazach zjawiska, będące efektem spotkania przedstawicieli Zachodu i Wschodu, są doskonale widoczne po okresie zmian systemowych, kiedy z oczywistych względów kontakty uległy intensyfikacji. Często jest to przedstawienie funkcjonujących stereotypów, odtworzenie schematów, które są na nowo opisane. Istotną różnicą w stosunku do wcześniejszej historii jest to, że spotkanie nie jest wynikiem exodusu spowodowanego wojną czy inną dziejową klęską dotykającą całych społeczności. Jest możliwe dzięki pozytywnym przemianom, otwartym granicom i pojawieniu się mieszkańców Zachodu nad Dunajem.

Do najbardziej aktualnych problemów związanych z ruchami migracyjnymi w Europie nawiązuje częściowo Kornel Mundruczó w swoim filmie Księżyc Jowisza (Jupiter holdja, 2017). Ten trudny do sklasy-

${ }^{3}$ Co ciekawe, to nie jedyny film z udziałem aktorki, w którym gra ona tego typu postacie. Innymi przykładami są filmy: Morderca z kamerą (reż. Robert-Adrian Pejo, 2010) oraz, ostatnio, Upolowana (reż. Áron Mátyássy, 2015). Można właściwie zaryzykować stwierdzenie, że jej bohaterki są symbolem złych wyborów i tragicznych związków. 
fikowania pod względem gatunku obraz uzmysławia kryzys moralny, który jest wynikiem kryzysu migracyjnego. Węgry doświadczyły go bardzo mocno, tysiące przybyszów z dnia na dzień pojawiły się na terytorium kraju forsując granice, wkrótce blokując ulice i dworce stolicy. Odpowiedzią był krytykowany powszechnie prowizoryczny mur wybudowany na granicy węgiersko-serbskiej w 2015 roku, którego celem było ograniczenie napływu, jak sądzono nie tylko uchodźców, ale także imigrantów ekonomicznych. Media obiegały nieustannie relacje z tymczasowych obozów i o koczujących w nich zdesperowanych ludziach.

Choć reżyser sam unika jednoznacznej odpowiedzi, że jego film jest reakcją na problem migracji, to jednak przyznaje, że:

„Musimy zrozumieć, że ten bodaj największy problem naszych czasów nie wziął się znikąd. Kryzys imigracyjny stanowi w prostej linii pochodna ogarniającego Europę od lat kryzysu moralnego, który wywołuje poczucie niepewności i strachu. Przez lata odczuwaliśmy te emocje podskórnie, gdzieś we własnych wnętrzach. Pojawienie się uchodźców okazało się impulsem prowadzącym do uwolnienia tej negatywnej energii i, niestety, skierowania jej na ludzi, którzy najmniej w ogóle na to nie zasługują" [Czerkawski 2018, s. 177].

Mundruczó w swoim filmie opowiada historię młodego uchodźcy Aryana, który dociera do granicy węgierskiej z ojcem i nielegalnie próbuje ją przekroczyć. W wyniku akcji służb granicznych traci z nim kontakt, sam ranny trafia do obozu dla uchodźców. W wyniku odniesionych ran umiera. Jednak ta dramatyczna historia nie kończy się w tym miejscu.

W jakiś niewytłumaczalny sposób zmartwychwstaje i dodatkowo zyskuje moc unoszenia się wbrew siłom grawitacji. Dla opiekującego się nim wcześniej, sfrustrowanego własnym nieudanym życiem, lekarza Sterna jawi się niczym anioł, który może odmienić jego życie. Początkowo jednak będzie jego zdolności wykorzystywał dla podreperowania swojej kiepskiej kondycji finansowej, organizując płatne pokazy boga- 
tym pacjentom. Z czasem jednak zmieni się jego nastawienie i zrobi wszystko, aby uchronić Aryana przed poszukującymi go służbami.

W tym filmie Mundruczó nagromadził wiele różnych konwencji i elementów odmiennych gatunków filmowych. Dominuje paradokumentalna narracja, szczególnie w początkowej części filmu, są też motywy znane z filmów sensacyjnych, thrillerów, z kolei postać anioła przybliża opowieść w kierunku baśni [Helman 2018, s.194]. Można odnieść wrażenie, że sam do końca nie był przekonany, którą drogą powinien zmierzać. Ta niekonsekwencja jest widoczna szczególnie w rozwiązywaniu scen, które byłyby ślepą uliczką, gdyby nie element magiczny i zdolności Aryana. Z kolei wiarygodne wrażenie tworzą sekwencje w obozie dla uchodźców, zostały sfilmowane precyzyjnie, bez uproszczenia, lecz z pełnym dramatyzmem i nieskrywanym współczuciem dla ofiar. Akcja filmu rozgrywa się niezwykle szybko i nie zmienia tego fakt, że mamy do czynienia z długimi ujęciami wyreżyserowanymi montażem wewnątrzkadrowym.

Postać lekarza Sterna dla Mundruczó ma stanowić reprezentacje zmanipulowanego przez część mediów społeczeństwa niechętnego, podejrzliwego wobec uchodźców. Sternowi brak empatii, jest wypalony, zmaga się z poważnymi oskarżeniami o zaniedbania w zawodzie. Cud jaki ukazuje się na jego oczach próbuje początkowo zdyskontować dla poprawy swojej sytuacji. Gdy szanse na ukrycie Aryana maleją, rezygnuje z własnych korzyści i ryzykuje własnym życiem by go ocalić, być może dostrzegając większy plan, który Aryan ma zrealizować. W filmie widzimy Węgrów przytłoczonych, zaskoczonych skalą problemu, przybysze dosłownie zalewają stolicę, a efektywnej odpowiedzi jednak brakuje, tymczasowe obozy nowej sytuacji nie rozwiązują.

Z innej perspektywy kwestie migracyjne prezentuje Roland Vranik w filmie Obywatel (Állompolgár, 2018), którego bohaterem jest Wilson, czarnoskóry mężczyzna w średnim wieku uciekający przed wojną w Afryce. Vranik sfilmował tradycyjną linearną opowieść, w której brak 
jakikolwiek transgresji gatunkowych, są natomiast dramaty zwykłych ludzi. Ciekawe i warte podkreślenia jest, że w filmie otoczenie Wilsona jest w stosunku do niego przyjazne, bardzo rzadko zdarzają się przejawy rasizmu (np. ze strony zazdrosnych o sukcesy kolegów z pracy). W rozmowach z Wilsonem Węgrzy nie ukrywają swojego zdziwienia, że chciał zostać na Węgrzech, mógł przecież uciekać na Zachód. Trudno jest mu im wytłumaczyć, że znalazł już dla siebie azyl i spokojne miejsce do życia, ma mieszkanie, pracę, bezpieczeństwo, do pełni szczęścia brakuje zdanego egzaminu państwowego i obywatelstwa. To uporządkowane życie zmieni się całkowicie, kiedy do jego drzwi zapuka potrzebująca pomocy młoda Iranka, uciekinierka z obozu dla uchodźców, w dodatku w ciąży i bez dokumentów. Wilson znając uczucie strachu, które towarzyszyło mu wcześniej, stara się pomóc ukrywając Shirin w mieszkaniu. Paradoksalnie już po krótkim pobycie to schronienie zamieni się dla niej właściwie w więzienie: boi się wyjść na ulicę z lęku przed spotkaniem policji, nie może zapewnić opieki nowonarodzonej córce, a każdy dzwonek do drzwi budzi jak najgorsze obawy.

Portret Węgrów w tym filmie jest bardzo korzystny, trudno dostrzec jakąkolwiek barierę między Wilsonem a jego sąsiadami, współpracownikami, może dlatego, że zna język węgierski i nie potrzebuje tłumacza, chociaż nie wszystkie elementy kultury węgierskiej rozumie. Nie trafiają do niego argumenty o tym, że dawniej władcy mogli torturować swoich wrogów i było to usprawiedliwione. Sam doświadczył cierpienia i nie akceptuje go pod żadnym warunkiem. Jego kolor skóry nie ma dla nikogo znaczenia, np. dla administratora budynku najistotniejsze jest, aby on i jego nielegalna współlokatorka płacili czynsz, jak długo tak będzie, nie pojawią się z jego strony problemy.

Wilson, mimo że zadomowił się nad Dunajem to zdany egzamin państwowy (wcześniej tryumfalnie wykrzykuje na ulicy: „Będę Węgrem!”) świętuje w lokalu dla imigrantów. Jednak jest to zupełnie inne miejsce niż to znane z Bolse vity czy Czerwonego kolibra. Tu nie bawią 
się przestępcy czy mafiosi, lecz przy dźwiękach dyskotekowej muzyki tańczą przybysze $\mathrm{z}$ afrykańskich krajów. To zasadnicza odmiana w stosunku do wcześniejszych obrazów. Życie jest bardziej ucywilizowane, relacje międzyludzkie oparte są na szacunku, problemy, które się pojawią mają z jednej strony podłoże uczuciowe, z drugiej rozgrywają się na linii jednostka - machina urzędnicza. Wilson wikła się w romans ze swoją korepetytorką (Mari) przygotowującą go do egzaminu, a równocześnie postanawia zapewnić bezpieczeństwo Shirin i jej dziecku poprzez małżeństwo po ewentualnym otrzymaniu obywatelstwa. Być może romans jest wynikiem potrzeby udowodnienia, iż ma takie same potrzeby jak inni ludzie, chce kochać, śmiać się, tańczyć, itp. Warto dodać, że w roli kochanki pojawiła się Ágnes Máhr, aktorka, która grała w Bolse vicie Erzsi, Węgierkę przyjmującą pod swój dach przybyszów zza wschodniej granicy.

Wilson przegra jednak w zderzeniu z systemem państwa, nie może doczekać się obywatelstwa, by chronić Shirin i wkrótce zjawi się po nią policja. Próbuje nawet namówić swojego przyjaciela rzeźnika, aby ten wziął ślub z kobietą, jest jednak za późno, zostanie ona deportowana. Zrezygnowany porzuca Mari i z całym swoim skromnym dobytkiem rozpoczyna kolejną podróż, zaczynającą znowu wszystko od nowa, tym razem w Austrii. Z jednej strony widać chętnych do pomocy zwykłych Węgrów, z drugiej urzędników wykonujących swoje obowiązki bez możliwości zrobienia czegokolwiek, co nie byłoby usprawiedliwione literą prawa (choć prywatnie urzędniczka przeprasza nawet Wilsona, że tak ospale traktowani są imigranci z Afryki, a policjanci nie aresztują go, gdy awanturuje się pod budynkiem prezydenckim). Wilson inaczej niż bohaterowie przywołanych filmów, mimo wszystko bardziej zakorzenił się w otaczającej go nowej kulturze. Jednak decyzja o wyjeździe przyszła bardzo szybko, dlatego można sądzić, że ta więź była tak naprawdę powierzchowna, nie znalazł jeszcze dla siebie drugiej ojczyzny. 
Film węgierski w charakterystyczny dla siebie sposób reaguje na kryzys migracyjny, zarówno ten z przełomu lat 80. i 90., jak i najnowszy. Z jednej strony filmowcy starają się uchwycić zmiany jakie napływ mieszkańców innych rejonów świata wywołuje w mentalności Węgrów, jak reagują oni na obcych, czy potrafią się dostosować do nowej sytuacji. Interesuje ich także pewnego rodzaju ewolucja w sferze kultury, pojawiają się nowe zachowania, nowe elementy języka, który próbuje dostosować się innej rzeczywistości. Z drugiej strony twórcy obserwują jak przybysze aklimatyzują się nad Dunajem, jak postrzegają Węgrów. Nieliczni są otwarci na węgierską kulturę, dla innych to tylko balast, którego nie potrzebują w swojej nieustającej podróży, taka postawa może rodzić najwięcej konfliktów, antagonizuje przedstawicieli obu stron. Dalsza obserwacja będzie zapewne dotyczyła bardziej trwałych relacji, być może kolejnej generacji imigrantów mieszkających na Węgrzech.

\section{BIBLIOGRAFIA:}

Bársony, É., Ideológiai kalandfilm. Beszélgetés Fekete Ibolyával, „Filmvilág” nr 1, 2001, s. 42-43.

Czerkawski, P., Fascynująca melancholia. Rozmowa z Kornélem Mundruczó, „Kino”, nr 1, 2018, s. 78-82.

Helman, A., Transgresje i transformacje $w$ filmach Kornéla Mundruczó, „Kwartalnik filmowy”, nr 101-102, 2018, s. 174-197.

Schubert, G., Rejtözködő évtized. A kilencvenes évek stílusa, „Filmvilág”, nr 3, 2002, s. 20-21.

Stojanowa, Ch., Bolse Vita, The Cinema of Central Europe, ed. P. Hames, London-New York 2004.

Varga, Anna, A gyávaság kora, „Filmvilág” nr 2, 2007, s. 24-26. 


\section{FILMOGRAFIA}

Bolse vita (1996), reż. Ibolya Fekete.

Czerwony Koliber (Vörös Colibri, 1995), reż. Zsuzsa Böszörményi.

Helyfoglalás, avagy a mogyorók bejövetelé (1999), reż. András Szőke.

Księżyc Jowisza (Jupiter holdja, 2017), reż. Kornél Mundruczó.

Mix (2004), reż. Steven Lovy.

Obywatel (Állompolgár, 2018), reż. Roland Vranik.

Pikowanie (Zuhanórepülés, 2007), reż. Erik Novák.

Węgierski wędrowiec (Magyar vándor, 2004), reż. Gábor Herendi.

Zajęcie ojczyzny (Honfoglalás, 1996) Gábor Koltay. 